\title{
Racial Hatred and Unmourned Loss
}

\author{
by David Gadd \\ University of Keele \\ Sociological Research Online, 15 (3) 9 \\ $<$ http://unw.socresonline.org.uk/15/3/9.html> \\ $10.5153 /$ sro. 2208
}

Received: 22 Mar 2010 Accepted: 6 Aug 2010 Published: 31 Aug 2010

\begin{abstract}
This paper explores the way in which Freud's theory of melancholia is being used within sociological theory to explain racial hatred in Britain. The paper critically interrogates the work of Paul Gilroy before engaging with the works of Eric Fromm, Richard Sennett, as well as Freud and Klein's classic psychoanalytic formulations. Using two biographical case studies drawn from original empirical research on racial harassment perpetrators the paper argues that while racial hatred is often melancholic in nature, the losses at the heart of the racist's malaise tend to be only tangentially connected to empire and its crimes. More commonly, the losses that underpin hatred are irreducibly personal and class based, and hence multilayered, losses of love and security, for example, aggravating the pain of losses of respect and community, and vice versa. The paper concludes by drawing attention to the dangerously racialized kinds of imagined community losses of this kind tend to furnish, and the difficulties of providing recognition to those most afflicted by them.
\end{abstract}

\section{Keywords: Melancholia, Mourning, Racism, Hatred, Loss, Paul Gilroy}

\section{Introduction}

1.1 In sociology, oral history, and cultural studies 'mourning' and 'melancholia', as Darian Leader (2009) quips, are becoming the 'new black'. Relating the symptomology of melancholia to the perception of cultural loss has become fashionable, particularly in relation to the analysis of nationalism, racism and human rights abuses by former colonial powers. Much of this writing is concerned with issues of representation, or framing, as Judith Butler (2009) would have it: with how some lives are defined as more dispensable and less grievable than others; with how the damage done to indigenous populations was erased from the historical record by their colonizers (Cowlishaw, 2004; Stanley, 2006); with the silencing of those who lost loved ones in international wars (Damousi, 2001); with the de-nazification of German family history (Welzer, 2008); and more latterly with the unmourned loss of civilian populations killed in the socalled 'War on Terror' (Butler, 2006, 2009). If there is a recurring theme in this literature, it is that losses that go unmourned continue to make their presence felt. They have effects - side-effects - that resurface in the hatred and spite that underlines the deficit of recognition those who carry them feel they are due. And this is how conflicts can escalate. Those who cannot acknowledge the losses that most trouble them have difficulty 'when in a state of pain to remain responsive to the equal claim of the other for shelter, for conditions of liveability and grievability' (Butler, 2009: 184). They become resentful, even hateful, towards those who are just as deserving of recognition, but whose markers of distinction - whether physical, cultural or historical - can be cited as evidence of their unworthiness.

1.2 In what follows I want to explore this insight in relation to case studies compiled from biographical interviews I conducted with people accused of, or involved in, racial harassment living in North Staffordshire, in the United Kingdom. As I will show through an analysis of what the most hateful of these individuals said, the painful personal losses of love, respect and dignity in their lives was quite evidently connected to their particular investments in racism and xenophobia. Before introducing these case studies I wish first to explore how melancholic responses to loss have been conceived as a cause of racism among sociologists who have drawn on psychoanalytic concepts. I look first at the work of Paul Gilroy (2004, 2006a/b) - and the support to be found for part of his argument in analyses of the British Social Attitudes Survey - before reflecting on how Gilroy's analysis differs from the earlier formulations of Eric Fromm (1942/2002); the ongoing research of Richard Sennett (1993), alone and with Jonathan Cobb (Sennett and Cobb, 2003); and the classic psychoanalytic formulations of Sigmund Freud and Melanie Klein, among others. 
2.1 Paul Gilroy's argument - made in After Empire (2004), Postcolonial Melancholia (2006a), and his inaugural address to the LSE $(2006 \mathrm{~b})$ - is that $21^{\text {st }}$ century British nationalism is inherently melancholic. Gilroy argues that the British continuously reinvigorate the victorious sentiments of 'two world wars and one world cup' to keep the legacies of their colonial past out of mind:

The life of our nation has been dominated by an inability even to face, never mind actually mourn, the profound change in circumstances and moods that followed the end of the Empire and the consequent loss of imperial prestige. (Gilroy, 2004: 98)

2.2 The British, Gilroy argues, cling neurotically to the mythology of the 'great' anti-Nazi war of the 1940s because it keeps unsettling knowledge about their nation's fall from grace out of mind. Gilroy suggests that, because there has been no mourning of empire's passing, because the British cannot and will not let it go, a cultural melancholia has set in.

[F]or Britain, developing durable and habitable multiculture depends upon working through the legacies of empire. That outcome is currently frustrated by a social, cultural and psychological blockage I call postcolonial melancholia. (Gilroy, 2006b:2)

2.3 Gilroy argues that British nationalism is characterized by a 'disavowed identification with the empire and its crimes' (ibid: 26) that gives rise to the symptoms of melancholia, evidenced in: a culture of neurotic selfloathing projected out as xenophobia against immigrants with whom we are imagined to be at war; political ambivalence about admitting to the enduring damage done to former colonies by British imperialism; and recurring anxieties over the prospect of British subjugation to the neo-colonialist war-mongering of the USA. While welcoming the emergence of convivial youth multi-cultures in Britain's metropolises, Gilroy notes how many in Britain have become dependent on the 'certainties' of 'race-thinking' to 'keep their bearings in a world they experience as increasingly confusing' (ibid: 116). Postcolonial melancholia blinds us to the connections between 'race-thinking' and the white supremacism that legitimized colonial endeavour, so much so that we fail to notice that racism is a problem until the 'next tragic death or inflammatory eruption' shakes us temporarily out of our complacency (Gilroy, 2006b: 5 , emphasis in original). This 'pattern in which quieter periods of apparent forgetting that endure long enough for the inevitable lament of "we did not know" to appear plausible', is (ibid, emphasis in original) what makes it possible for hatreds to fester unchecked whenever the aura of British greatness is threatened (for example, when recession bites, international football matches are lost, or our military incursions into foreign lands are unwelcomed). At such moments, the advocates of multiculturalism are 'subjected to ridicule and abuse' (2006a: 2) while hate for immigrants and minority ethnic groups is accentuated, not through the consumption of 'supposedly reliable anthropological knowledge of the stable identity and predictable difference of the Other' as it was in colonialism's heyday, but because in postcolonial times 'the Other's difference in the commonsense lexicon of alterity' has become impossible to 'locate'.

Different people are hated and feared, but the timely antipathy against them is nothing compared to the hatreds turned toward the greater menace of the half-different and the partially familiar. To have mixed is to have been party to a great civilizational betrayal. Any unsettling traces of the resulting hybridity must therefore be excised from the tidy, bleached out zones of impossibly pure culture. (2004: 137)

2.4 And this is why, Gilroy concludes, a catalogue of enemies within - the insidious Muslim 'extremist' living quietly among us, the 'bogus' asylum seeker passing himself off as a 'deserving' refugee, together with long settled but allegedly 'self-segregating communities', and more or less anyone who, because of their appearance, lifestyle, or accent is just a little hard to place - have all become the focus of public outrage.

\section{Racism, war, and the hidden injuries of class}

3.1 There is much in Gilroy's analyses that is compelling. The legacy of the great anti-Nazi war is such an integral part of white British family history that even those of us alive to issues of nationalism and its poor relation, violent racism, often fail to notice how much it inflects our understanding of the present (Collins, 2004). Racism continues to fester in Britain, despite the New Labour government's promise back in 1997 that 'things' would only get better with respect to crime, poverty, and in lieu of the wake up call provided by the Inquiry into the police's handling of the murder of Stephen Lawrence, racism and its pernicious effects. As the national outpouring of grief after the murder of Merseyside schoolboy Anthony Walker revealed, people continue to be shocked by those racist murders that hit the headlines. But the connection between this shock, pervasive disinterest in issues of racial equality and significant upturns both in the number of the number of people admitting to being racially prejudiced in the British Social Attitudes Survey post 2001 (McLaren and Johnson, 2007) and the number of racist incidents experienced by victims as measured by 
3.2 The nature of the racist prejudices held by people in Britain is however, a little more complexly differentiated than Gilroy assumes. A recent ICM poll of adults in Britain, for example, revealed that the majority of the population now hold misconceptions about Islam, irrespective of their class, age or place of residence (ICM, 2009). Conversely, the assumption that immigrants are treated more favourably with respect to housing and welfare benefits increases with age, is more predominant in the Midlands and North West of England, and a little more pronounced among the socio-economic groups C2DE than among ABC1s (see also Crawley, 2005). Analyses of the British Social Attitudes Survey, however, suggest that socio-economic grouping, being on benefits and/or being unemployed are relatively poor predictors of hostility towards immigrants: 'those with better incomes, better educations and higher status occupations are just as hostile to immigration as their lower status counterparts' (McLaren and Johnson, 2007: 721). The British Social Attitudes Survey reveals that hostility towards immigrants at the aggregate level is predicted more by 'concerns about the loss of certain values or ways of life' than 'personal self-interest' (p723). In sum, there is empirical support for Gilroy's argument that Britons' attitudes to ethnic diversity are often more melancholic than convivial. But this in itself begs the question as to what makes some people more melancholic - i.e. more preoccupied with loss - than others, as well as why it is that only some of those so afflicted allow the hate loss evokes to become so racialized.

\section{Psychoanalytic sociology and 'hidden’ class injuries}

4.1 Earlier sociological attempts to utilise psychoanalytic concepts to explore authoritarianism tended to address this question more directly than most contemporary writing about racism. In his attempt (first published in 1942) to explain receptivity to Nazi ideology among the German lower middle class, Eric Fromm, for example, argued that fascism appealed to the 'diabolical forces' (2002: 5) aroused by the terrifying fears of loneliness and insignificance that accompanied the growth of freedom and the loss of traditional bonds of deference and authority under capitalism. Fromm observed that while the German working class became resigned to Nazism, more through a fear of being perceived as 'unpatriotic' than through any positive affinity to its ideology, the lower middle classes were gripped by it. Having identified closely with aristocratic values only to see the demise of royalty's influence under capitalism, Nazism compensated the lower middle classes emotionally for their loss of authority. Their feared social inferiority was projected onto the Jews, Roma, Communists and homosexuals could all be blamed for national decline. The German working class, by contrast, did not feel the same sense of cultural loss, having been less aligned with aristocracy in the first place, and having been commended for how well they had fought in the First World War, despite their defeat.

4.2 Today, British sociological attention has focussed more on the white working class, or at least an 'embattled section' of it who, according to Stuart Hall (1999: 193) are invested in a 'form of violent collective projection which follows the classic logic - "We are poor because the blacks are here"': 'They have few employment or educational prospects, feel a deep sense of national shame and dispossession'. Who these people are and why they feel this way, however, has not always been approached as sympathetically as it could be (Collins, 2004; Sayer, 2005). Richard Sennett's work, alone and with Jonathan Cobb (Sennett, 2003; Sennett and Cobb, 1993) presents one of the more sophisticated exceptions. For Sennett and Cobb the question was how the experience of being continuously disrespected inflicts hidden psychological injuries on white working class people. Sennett and Cobb's argument is that in the US and Britain today the working class have become increasingly defensive about the freedoms and dignities they have had to live without. Because they cannot get anywhere in the class structure they can only suffer the "buried sense of inadequacy' that comes from 'contrasting oneself to those at a higher social level' (ibid: 58 ). This is why:

Working-class fathers ... see the whole point of sacrificing for their children to be that their children will become unlike themselves ... [H] is sacrifice does not end in his own life the social conditions that have made him feel open to shame, prey to feelings of inadequacy. To call the pressure working-class fathers put on their kids 'authoritarian' is misleading in that the father doesn't ask the child to take the parents' lives as a model, but as a warning. (Sennett and Cobb, 1993: 128)

4.3 It is also why the anger and resentment felt by poor whites towards the liberal elites (to whom they have to explain their dependency) and the poor blacks and migrant workers (just below them in the class structure) is so easily channelled by opportunist politicians into racism, the condition of 'not being seen' inducing a 'desire to avenge'. From this perspective, white racism is a defence against the fragility of working class 'honour' (ibid: 45), even if, as Sennett has since expanded, it is not reducible to the sociological effects of class structure. Inspired by the insights of the (object relational) psychoanalyst Donald Winnicott, Sennett concludes his (2003) book, Respect, with the observation that we have also to get to grips with the relational dimensions of issues of personal character if we want to reinstate respect among those injured by class and its hurts. 
Treating people with respect cannot occur simply by commanding it should happen. Mutual recognition has to be negotiated; this negotiation engages the complexities of personal character as much as social structure. (ibid: 260 )

\section{Classic psychoanalytic theorizing}

5.1 Freud, of course, understood only too well, the significance of this relational dimension, matters of personal character - his own and those of his clients - infusing transference relationships that had to be worked through in order to comprehend the presenting hysteria. These transference relationships tended to be infused with unconscious fears of loss and concomitant desire for what had, or was about to be relinquished. The genius of Freud's essay (1917) 'Mourning and Melancholia' was to notice that the emotional turmoil we feel when a loved one dies is psychically similar not only to the pain we feel when are estranged by those we love, but also to how we are affected when we are slighted by those whose recognition we desire. Because we usually do not realise how closely we identify with others, or how dependent we are on them for their respect and recognition, we sometimes find it difficult to anticipate in what circumstances we will experience loss, and harder still to comprehend that our feelings of depression are products of losses we are unable to come to terms with. Consumed or 'eaten up' by an unbearable loss, the melancholic is, by definition, someone who cannot love again, hence their hate, envy and misery. Rather than embarking on the painful working through of what it is in oneself that has been lost - the process of mourning - melancholics swallow their feelings whole in a form that is barely digestible, before having to live with the tormenting discomfort of keeping this undigested psychic matter down (Cheng, 2007: 138). Consciously, the melancholic 'is not of the opinion that a change has taken place in him' yet, unconsciously, he 'reproaches himself, vilifies himself and expects to be cast out and punished' (Freud, 1917/1957: 246). He takes 'refuge in narcissistic identification' that renders all difference intolerable. This is what brings 'hate... into operation' (ibid: 251). Substitutive love objects are sought so that 'sadistic satisfaction' can be derived from their 'suffering' (ibid). Meanwhile, unbearable feelings of powerlessness are kept at bay by 'thoughts of suicide' that alternate with 'murderous impulses against others' (ibid: 252).

5.2 While psychology textbooks tend to depict psychoanalysis as beginning and ending with Freud, Freud's theory of mourning was developed further by Melanie Klein, his daughter Anna, as well as a raft of contemporary relational thinkers for whom issues of identification and recognition are central. Klein (1935, 1940) argued that to fend of feelings of vilnerability small children are constantly attacking in fantasy, if not also in reality, their primary carers; carers upon whom they feel intensely dependent, even psychically merged. As the child attempts to establish its autonomy and independence it falls prone to paranoid schizoid thinking. It sadistically attacks its mother, only to realize again its dependence on her, its need to be noticed, recognised and needed by her. Thereafter, it has to undergo a process of mourning, whereby the lost love object - its internal fantasy of the loving and lovable mother - can be restored as part of the self. This mourning entails surviving feelings of guilt, and the ambivalence of the depressive position accepting that we often feel both love and hate towards those upon whom we depend - so that reparation can be made.

5.3 All of this, of course, is contingent upon whether the care provided to the child is, in Winnicott's (1958) terms, 'good enough', with the consequence that as adults, some of us struggle more than others to cope with the fluctuations between paranoid-schizoid and depressive thoughts. We live, as Anna Freud also observed, in the constant shadow of loss; afraid of losing both those we love and the love of those we love.

There is no scar in mental life which cannot reopen under specific conditions. If this happens, the whole structure of the personality is shaken to the core. (Freud, A: 1964: 235)

5.4 In other words, the smallest slight can open up new wounds and old, aggravating the emotional scars left by deaths, estrangements, humiliations and disgraces, along with the traumas of childhood relational crises (Leader, 2009). Because loss tends to be felt as such a deeply privatizing experience it tends, also, to promote nostalgia, the re-imagining of protective communities that will restore us to some former state of completeness. As Judith Butler has argued:

[W]hen we lose someone, we do not always know what it is in that person that has been lost. So when one loses one is faced with something enigmatic: something is hiding in loss, something is lost within the recesses of loss... On one level, I think I have lost "you" only to discover that "I" have gone missing as well. At another level, perhaps what I have lost "in" you, that for which I have no ready vocabulary, is a relationality that is composed neither exclusively of myself nor you, but is to be conceived as the tie by which those terms are differentiated and related... Many people think that grief is privatizing... But I think it furnishes a sense of political community of a complex order... (Butler, 2006: 21-22, emphases in original) 
5.5 Butler (2009) is optimistic about the progressive possibilities grief can furnish: that it may foster a sense of political community open to repairing the damage done to the world by the War on Terror, for example. In what follows, I do not wish to dismiss this possibility out of hand. However, as the following case material illustrates, the losses suffered by sections of those communities blighted by industrial decline are so unbearably painful, multiply layered, and intricately relational, biographical and cultural, that it is difficult to foresee how the highly racialized 'sense of political community' evoked to soothe them can be easily dislodged.

\section{Putting the theory to the test}

6.1 In what follows I wish to explore the ways in which loss furnished a dangerously racialized sense of community for two individuals I interviewed in the course of a research project my colleagues and I conducted in Stoke-on-Trent between 2003 and 2005 (Gadd, Dixon and Jefferson, 2005) ${ }^{[1]}$. Otherwise known as the Potteries, the city of Stoke-on-Trent is closely associated with the production of pots, as well as coal and steel. Neither successive attempts at regeneration, nor a decade of New Labour initiatives, have been able to reverse the social consequences the decline of these industries has wrought, some socio-economic analyses suggesting that the city is the only one in Britain to have not come out of recession at all since 1974 (Harding and Nevin, 2009). And while there is a potentially admirable history of support for refugees and anti-racist activism to be written about the region, this is increasingly obscured by electoral support for parties of the far right. At the time of writing, a record nine British National Party councillors serve on Stoke-on-Trent city council.

6.2 Our research within the city explored some of this history and drew upon a range of sources, but its original empirical material derived from two key methodological interventions:

(1) Focus group discussions were conducted with thirteen groups of local people. These included groups from a residents association, a neighbourhood watch, a working men's club, a day centre for the elderly, two anti-racist groups, young offenders, asylum seekers, and white and minority ethnic users of two local authority run youth clubs.

(2) Free Association Narrative Interviews were conducted with fifteen men and women - aged between 15 and 65 - implicated in acts of racial harassment or violence (Hollway and Jefferson, 2000). Twelve of the 15 were accessed via probation services and youth offending teams (although only five of them had ever been charged with racially aggravated crimes). The remaining three, all of whom were politically involved in racist/anti-immigration political groups, were recruited through more direct approaches. Each were invited to tell their own lifestories over the course of two, occasionally three, in-depth interviews in which narrativeorientated questions, minimalist probes and active reflection were deployed by the interviewer to both facilitate recollective story-telling and explore around defensive self-justifications and rationalizations on the interviewees' part. All interviews were recorded, fully transcribed and used to inform the development of subsequent follow-up questions that probed the biographical dimensions of racism, hatred, and interpersonal violence. Our presumption, when it came to the analysis was that each our interviewees could only be understood through the interpretation of the entirety what they had said (and in some instances, had not said). We created pen portraits of our interviewees that tried to capture the complexities of the people we interviewed: the contradictions in their attitudes, the tensions between what they claimed and their actual experiences, evidence of care, compassion and tolerance as well as expressions of xenophobia, hatred and intolerance.

6.3 The picture that was painted of the locality by almost everyone in our focus groups was one of enduring economic decline, cultural loss, and political abandonment. When industries and jobs were lost, so were vibrant and cohesive working class communities (Gadd, Dixon and Jefferson, 2005). At the mercy of 'absentee landlords' and uncaring housing providers, older people complained that respectable neighbourhoods had become 'dumping grounds', and/or 'breeding' grounds, for 'foreigners' and 'riff-raff. Parts of their city were said to have come to resemble a 'war zone', 'Beirut', 'Africa' or 'Bombay'. Younger people identified with their elders' sense of themselves as victims of discrimination imposed by a 'politically correct' elite that not only expected the worst of people like them, but consistently put the needs of those who 'did not belong' before all others. These needy 'foreigners' were widely perceived as both a symptom and cause of Stoke-on-Trent's current decline: evidence of the demise of 'community' in previously homogenous working class neighbourhoods and responsible for much of the crime, disorder and drug abuse that affected the quality of local people's lives. 'Gypsies' and other 'riff raff' were described as outcasts, but 'Pakis', 'immigrants' and 'Kosovans' were much more widely vilified. Racism and hatred did not always go and hand in hand, however. Despite the offensive language used to describe them, those perceived to be 'blacks', 'niggers' or 'half-castes' were generally depicted as 'safe' and 'sound', hard- 
working and trustworthy, while almost everyone who could not fit into this black/half-caste/white lexicon was regarded with suspicion, and in many cases, assumed by definition to be predatory, lazy, and/or disrespectful outsiders, irrespective of where they were actually born or what they did for a living.

6.4 Within our sample of fifteen racial harassment perpetrators we included those who had been accused of promoting racism through their political activism, as well as individuals suspected of having perpetrated racially aggravated crimes, whether or not they had been convicted of these. Although at least seven of these interview participants had, at some point in their lives, been routinely involved in violent crime, their racism tended to be as paradoxical - sometimes even more so - than that expressed by the participants in our focus groups. Some had black friends, while others were keen to distinguish those Asian people they got on with from those they did not. Addiction and mental health problems, together with experiences of childhood abuse and neglect tended to be quite distinguishing features of the 'perpetrator' sample, perhaps explaining how losses of love and respect, as the following two case studies illustrate, became implicated in their expressions of hatred. The two life-stories discussed below were chosen for this paper as they were provided by the two participants in the Free Association Narrative Interviews who were the most unashamedly forthright in their racism. They were also, perhaps relatedly, the two sets of interviews that caused me, the interviewer the most personal discomfort. While analysing the interviews with Nigel, I suffered nightmares in which I felt pressured by him to endorse a demonic view of Islam I do not share so as not to offend a participant who had gone out of his way to be hospitable towards me and had been painfully honest in his responses to my questions. Similarly, I struggled for some months to make progress in analysing my interviews with Stan, in large part because I coped with the unease I felt about hearing myself on tape laughing as he laughed got in the way of developing an account that was sympathetic to the terrifying childhood experiences he had had to come to terms with.

\section{Nigel}

7.1 A prominent BNP activist in his neighbourhood - a former mining village where he had lived his entire life - and regarded by some residents in that neighbourhood as having incited the racial harassment their minority ethnic friends and relatives were being subjected to, Nigel had good reason to be on the defensive. A middle aged white man who insisted that he was not a racist (because he had 'black friends' and 'half castes' in his own family) and neither was the BNP (because they oppose all crime, including racist crime) Nigel had a stock explanation for his controversial political affiliations. Tony Blair had 'lied' to 'the country' about weapons of mass destruction; 'illegal immigrants' were putting the health service under enormous pressure; 'terrorists' were being 'allowed' to remain in 'Great Britain', while Muslim clerics looking to turn Britain 'into an Islamic state' were peddling hate with impunity. Nigel had joined the BNP in order to 'stand up' to all those 'ethnic members' who were 'attacking' his 'culture': 'I will never, ever allow any other ethnic member of any country, of any religion, to attack my culture'. Yet, when invited to tell his own personal story, Nigel offered a very different account. He cried as he revealed a childhood that was so unhappy he contemplated 'throwing' himself under a neighbour's car at the age of 8.

I used to spend a lot of time coal picking ... I remember me dad was working sometimes and sometimes he was unemployed. We were poor but we all stuck together... I missed out on a lot of things ... Me dad was pretty hard on me personally like. And me mum was always very protective and, ur, I never forget the first time that ur ... All the local school children used to talk about the discothèque ... [M]e mum finally let me go one day. Me dad ... went away on Friday for a two week holiday to the miners' homes ... And the Monday come [3] and ... I went to the discotheque [becoming breathless] ... [15] When I got [6], when I got back home [crying] me mother, me mother had died... So it's just something I can't ever forget really.

7.2 Sharing a council house with a large family of pot bank and pit workers, times were very hard during Nigel's youth. His sometimes-employed, sometimes-unemployed, father and housewife mother raised nine children, of whom Nigel was the seventh, in a three bed-roomed property they shared with Nigel's grandmother. As a child so much of Nigel's time out of school was spent running errands and picking coal that he had few friends. After school Nigel would be sent to the butcher's shop to buy food for the family's 'workers', but at mealtimes he would have to sit waiting 'like a dog', begging his older siblings to leave something on their plate for him to eat. His mum sometimes fell foul of her husband's temper, but she did her best to protect Nigel, reminding him to keep quiet and sending him to bed when his dad returned from the pub. Not knowing why his father had treated him so diminutively still troubled Nigel: 'I don't know why he kept picking on me ... I don't know if I was a cheeky kid.' Difficult though things had been while his mother was alive, Nigel's memories of events after her death were particularly painful. Her passing was compounded by his father's callousness:

He said, 'Is this you?' [3], meaning is it me that's caused me mum to, you know. That really hurt. 'Is this you? Carrying on?' That's all he said ... No hug. 
7.3 Soon after this, Nigel's girlfriend fell pregnant. Forced by his father to choose between living at home and supporting his girlfriend, Nigel fulfilled his 'moral duty' and moved out, even though their house had gained a spare room after Nigel's grandmother passed away. Nigel's loyalty to his father was unshaken by the ultimatum - 'I still respected me dad because he was me dad and, looking back, it must have been hard for him'. A suitable scapegoat for the hurt his father's actions caused was soon discovered though. Nigel and his girlfriend moved to rented accommodation where an Asian landlord exploited the couple's predicament, insisting that Nigel clean the house every day for a pound a week. The other (Asian) men who lived in the house 'always used to come in late at night because they'd been working on the pot banks ... cooking their curries ... and talking loud'. From this experience Nigel felt able to generalize: 'I've lived with them as well Dave ... and they treated me like shit'. Evicted by their landlord after refusing to do any more cleaning, Nigel and his girlfriend's relationship became strained and the two children they had together were taken into care. Nigel 'couldn't handle' this, 'was crying all the time', still thinking about his mum, and ended up taking an overdose.

7.4 An atheist who 'wished' he 'had a faith', Nigel's subsequent marriage to a devout Catholic woman, Mary, had the potential to appease things. She had been willing to adopt his first two daughters, but social services insisted the girls be taken into care. Nigel sobbed as he recounted how he told a social worker that he would:

... never sign nothing ... and when my children [10] come looking, l'll look them straight in the eye with honesty and say that [4] it wasn't me.

7.5 Mary was to become the 'real breadwinner' of the family she and Nigel formed together, his explosive temper, recurring back pain, and poor mental health leading to his dismissal and/or resignation from a succession of semi-skilled manual jobs. 'Although I tried to forget the past', he explained, 'you can never forget the past. It still comes up from time to time': 'I think it stems back to the memories of my mum'. Eventually prescribed medication for 'chronic depression' in his forties, Nigel did not tell people he was ill though, only that he was 'out of work'. Rather than do nothing he campaigned tirelessly, trying to 'put something back' into his community, through charity events, campaigns to stop children 'being killed or run over' by traffic, and lobbying the council to clean up the children's play areas. The campaigning was so stressful it almost put Nigel in 'an early grave', causing him to retreat to a caravan near the miner's home where his father used to stay; a place where he said he could be with his own his 'own kind', his 'own community', even though when there he spent a lot of time alone struggling 'to get to grips' with himself. Nevertheless, Nigel said he persisted with the campaigning because he wanted his children to be able to say, 'My dad's done that, and my dad's done that'.

7.6 Sadly, this kind of recognition never materialised, a succession of new losses, re-opening the earlier emotional wounds of Nigel's youth. First, Nigel's wife's had a miscarriage, leaving the couple with feelings of 'emptiness' exacerbated by their inability to pay for a funeral for their stillborn child. Second, after a long period of trying to raise funds to buy his father an electric wheelchair, the old man died. To Nigel's great distress his eldest brother had instructed the funeral directors not to bring the body into the house after the 'bit of money' for 'everyone' that their father had promised failed to materialise. Third, Nigel's two estranged daughters did 'come looking' for him, but Nigel had not been able to get back 'the bonding' that had been so painfully lost when the girls were taken into care. Nigel blamed his former partner - 'now going with a coloured chap' - for 'poisoning' the girls' minds against him. Finally, another of Nigel's daughters was turned down by the council for a 'budgeting loan' she had applied for, having become separated from her partner. Nigel begged and borrowed from his family to raise the deposit for privately rented accommodation. He described this as 'one of the lowest times' in his life - 'embarrassing and ... shocking' - before offering a revelation that shed new light on his political affiliations.

I felt as if ... the country has let us down badly. My daughter's worked for nine years ... The only time she has ever asked the government for any help, help she would be paying back, they turns us down. And that is when I joined the BNP.

Asked to expand on this, Nigel response only underlined how inextricably connected to the losses of his younger years his BNP activism was: 'They took me children away, me grandchildren away. That's when I got involved'.

\section{Stan}

8.1 Stan was a 19 year-old white man, serving a two-year custodial sentence for racially aggravated threatening behaviour, affray, actual bodily harm, and criminal damage. The incident that had led to these convictions occurred when Stan had been smoking marijuana at his mate's house. Lisa, a fifteen year old girl with whom Stan had previously had 'oral' sex, arrived complaining that 'the Asian geezer down the kebab house' had asked her for a 'blow-job'. The kebab shop worker had apparently hit Lisa in the face, 
giving her a swollen eye, when she refused. Stan's response was to make Lisa a cup of tea and give her a smoke, before going 'dead mad':

I thought, "Fuck it. That's it. Paki bastard". Got ballied up... I've got the pool cue at the side of me, like the fat end... I've said to him ...: "Can I order some food?"... As he's looking down. Pulled it down. "Want this", bam, bam, bam, about 3 or 4 times over the head with it. Then l've just legged it.

8.2 A 'riot' ensued on Stan's estate - one of the most deprived residential neighbourhoods in the region - as the kebab shop worker's friends sought out Stan and his mate, this mate having vandalised the kebab shop worker's car while the assault was ongoing. Stan recollected the riot with some nostalgia, describing it as: 'Fucking mad...people getting hit with bars, slashed and everything'.

8.3 Neither the extremity of this violence nor its unashamedly racist overtones were uncharacteristic of Stan's behaviour. An accomplished dealer of class ' $A$ ' drugs, Stan had become the owner of a balaclava a year prior. Participation in armed assaults on individuals, shops and other drug dealers were activities he associated with his entrance onto the 'big time scene', whereupon he started to 'get rid of everyone... go eat them... rob them': 'I started killing it off man, eating every thing up'. Before the assault on the kebab shop worker, he had only narrowly escaped a prison sentence for hospitalizing a 'Kosovan geezer' he believed to have groped his girlfriend - a 'half-caste' model with whom he had fallen 'stupid in love' - while they were out in a nightclub. Stan recounted rather gratuitously how the victim 'had to eat through straws'.

I don't feel bad... about it. Just think it's a laugh, a buzz. I break someone's jaw. I break someone's nose, I think it's a laugh. I love fighting I do. I don't know why.

8.4 Maybe Stan did not know why, but the brutal losses of love, childhood innocence, respect, and faith in the ability adult carers to shelter him from serious harm he endured repeatedly as a child were all possible sources of his peculiar sadism. Stan agreed to be interviewed because his head was 'all over the place' 'just battered' - and he was desperate to talk about it. Invited to tell his life story, Stan asked first for permission to talk about the 'bad' things in his life. Stan's father separated from Stan's mother when Stan was an infant; his father leaving to raise a 'good son' who became a successful businessman. After the separation, Stan's mother dated a succession of violent men, the first of which - Rob - Stan still wanted to 'kill, fucking mutilate'. Stan still had 'flashbacks' of Rob trying to choke his mum on the sofa, and of his own attempt - aged 5 - to crash a fish bowl onto Rob's head. The young Stan was so startled when the police crashed through the door he thought 'it was a bomb or something'. His mum was left 'crying with bruises on her face' while the neighbours stood 'staring in'.

8.5 At infant school Stan's behaviour became highly disruptive. He became a 'mad, stupid bastard' who would 'blow up like a volcano' at the smallest slight - the teacher saying his 'handwriting wasn't neat or I got a couple of questions wrong' taken to imply that he 'would not be going... nowhere in life'. While his mother started dating again, a female babysitter introduced Stan to sex when he was about 8 years old. Stan did not enjoy intercourse and worried about getting spots on his penis, but told no-one except a disbelieving friend. He blamed no-one, however, insisting that both he and the babysitter were 'fucking stupid'. Soon after Stan was suspended from primary school after he asked a female pupil to 'suck' his 'dick' and threatened the headmaster. At secondary school Stan's sexually inappropriate behaviour, persisted. He was suspended again after he locked a teacher in a cupboard, having first suggested she might like to have children with him.

8.6 Things improved a little when Stan's mum began dating Greg, a man Stan regarded as the 'dad' he 'didn't have'. Greg had taught Stan to 'play pool... shave... just everything'. But he had also attempted to have sex with Stan's mother while she was asleep and Stan, unbeknown to him, was watching. Stan said the memories of this 'rape' were 'buried away... still eating' him 'up inside'. Nevertheless, when Greg and Stan's mother separated, Stan blamed her and not him: 'She proper wrecked it like. Split me and me sister and my sister's dad up'. Stan's mother then fell 'stupid in love' with her current partner, the man with whom she had an affair: 'choosing him over me', as Stan recalled it. While this man's violence intensified, so did Stan's mother's alcoholism: 'I can just remember just going out the house....and she's opened the door come flying and kicking me and... her dressing gown has come off. And she was naked underneath there and me mates would have seen everything'. Stan said he still wanted to 'kill, fucking mutilate' his mother's lover.

8.7 Throughout his secondary years, 'fighting' - 'whites v Pakis' - was commonplace in Stan's school. The contrast between the powerlessness Stan must have felt as a child watching his mother's repeated abuse and the cowardice he attributed to those he deemed 'Pakis' could not have been starker.

These Pakis... they walk around... 'You can't do nothing to us. We fucking own this planet 
and that". Nothing but fucking scroungers... I hate them when they are in their gangs.

8.8 A 'proper little racist' by the age of 15 , having 'signed up for the NF' over the internet with one of his friends, Stan remembered with fondness the fights he used to orchestrate: 'We still got stories to tell from it'.

There was blood everywhere...It was heaving man... No holds barred shit. Serious, it was fucking evil. People ... stabbed in the neck, stamped on... It was just mad... [Laughs] A right little rampage. [Laughs] I hit all of them... All of them got hit.

8.9 Stan recollected the National Front March that incited the violence between Asian men and the police in Stoke-on-Trent during the summer of 2001 with a degree of (potentially sexualized) relish. The Asian boys he had fought at school were impotent to stop the march: 'I just grinned at them...What can they do? ... We're having it off with them.' On politics Stan had little more to say than: 'Blair just sucks Bush's dick'. Rather, for him the NF's appeal had everything to do with having that 'thing around' him, knowing that someone had his 'back': that 'they'll look after me.'

8.10 Now in custody, Stan was only just starting to realise 'what a dick' he had been. His mother, who when sober was 'the soundest mum', was heartbroken to learn that Stan had been using heroin, and so had written to say 'how much' she still loves him. Upon his release, Stan said he hoped to become a father and have his own family, if only he could avoid 'that stupid in love thing again'. But issues of race and sexuality were never far from his thoughts. He feared he was picking up the 'stupid little lingo' practised by the Asian prisoners so much so that he did not sound 'like a Stokie no more'. He had also learnt that a baby he had hoped to 'godfather' was going to be a 'Paki-baby': a revelation with which he did not think he could cope: 'I won't like him. I know I won't. But if it's her kid, I've got to love it'.

\section{Love, hate and loss}

9.1 While Nigel and Stan were both quite different people with quite different relationships to far right extremism and physical violence, there was indeed something about the quality of each man's racism that chimed very squarely with the description of postcolonial melancholia Paul Gilroy has provided. A 'halfdifferent ....partially familiar' ethnic other served as a repository for much of their hatred (Gilroy, 2004: 137). For Nigel these hated menaces were the 'Asian community' whom he conceived rather unwittingly as very much like the white working class he idealized: when the going got tough, they worked day and night, lived in crowded conditions, and 'stuck together'. The problem was that Nigel's family, despite his opening claims to the contrary, did not actually stick together. When the going got tough, as it did for many men in the coal, pot and steel industries, Nigel's dad got drunk and depressed and turned on his wife and children. In turn, the stress of hard work and the threat of underemployment took its toll on everyone. Nigel's dad, nevertheless, had to be respected, because he was their dad, and because he was the family breadwinner and the head of the household. Nigel's respect for his dad, however, could not conceal the damage done to at least three generations of children - Nigel, his estranged daughters, and now his grandchildren - who were simply not looked after by the family, the local white community, nor the local council. Rather than confront the emotional hurt these failings had inflicted, Nigel chastised 'ethnic members' of the community for failing to 'respect' his culture; for being half-different, partially familiar; for having everything he wished his family had been, including a level of religious conviction that a chronically depressed man, still devastated by the untimely death of his protective mother, would have almost certainly benefitted from.

9.2 In Stan's case a cowardly 'gang' of 'Paki-bastards' had become the folk-devils of his nightmares: men he unwittingly imagined to be rather like him. Like Nigel, Stan had grown up thinking he was a bad child who would come to nothing, but he appeared to externalise his hatred much more vociferously. A 'bastard', both because of the enjoyment he got from hurting others and because of his abandonment by a succession of father figures, Stan was dangerously predatory in his sexual behaviour - potentially more so than either the 'Kosovon geezer' or the kebab shop worker he 'battered' for their indiscretions. He felt menaced by the sexual improprieties of Asian men, whose 'stupid little lingo' he now perceived to be infecting his speech, and hence corrupting his connection to the locality. Nevertheless, Stan was unable to perceive himself as a victim of them or the various adults whose domestic and sexual violence had inflicted such crippling losses of love, innocence and personal security on him as a child. Forced to confront the fact of his mother's inability to protect him from either the terrifying violence of her partners or the judgemental stares of friends and neighbours, Stan identified, not with her vulnerability, but with one of her abusers: Greg, the father he never had. As a teenager, Stan equated love with stupidity - his own sexual encounters with women increasingly marred with aggression lest he fall 'stupid in love'. This aggression featured also in the violence he perpetrated against those minority ethnic men he construed as sexually predatory. Stan enjoyed physically punishing these men, safe in the knowledge that a gang of criminals and violent racists would protect his 'back'. 
9.3 In sum, both Nigel and Stan were consumed by losses they could not come to terms with. In Nigel's case there were suicidal thoughts; in Stan's many murderous ones. Nigel, in particular, was wracked with guilt, while Stan's head was 'battered' - much like his mother and the 'Pakis' against whom he sought retribution. In both his thoughts and within his community Stan was 'killing' off everything... eating everything up'. Nigel, meanwhile, was consumed by feelings of self-reproach. These feelings motivated his endeavours to do good within his community, his misguided BNP activism included. Fearing he really was a 'cheeky kid' who deserved to be castigated and belittled, Nigel had lived his life in anticipation of the day his daughters 'came looking'. He had internalized his father's castigating words and the judgmental gaze he feared his estranged daughters would subject him to. Likewise, for Stan the staring eyes of neighbours who had seen his mother battered, and friends who had seen her drunk and naked in the street, entailed a humiliating loss of respect that he too experienced as persecutory, his head psychologically battered.

9.4 In these respects both men's hatred bore the symptomology of melancholia. Both men had suffered unmourned losses that rendered them peculiarly hateful and highly dependent on racism. However, whether apropos Gilroy, it would be meaningful to suggest these men were identified with empire and its crimes is highly questionable. Certainly, postcolonial discourses around nation, community, and immigration normalized the hatred both men expressed within the kind of 'race-thinking' that had become culturally commonplace in their communities. Undoubtedly, the stereotypes of the 'self-segregating, self-serving Muslim community' and the 'violent and sexually predatory Asian gang member' had both popular and political currency during the periods when both men were interviewed (Alexander, 2004; Werbner, 2005; Webster, 2003). But as the case material above illustrates, the relationships between racism and hate among men like Nigel and Stan tend to be mediated across multiple layers of loss, the more immediate of which are both more intricately biographical and more complexly inflected by patterns of inequality than generalist cultural commentary can capture. Put slightly differently, while immigration, Muslims and ethnic minorities featured highly on the conscious agendas of both these men, losses of love, innocence, faith, respect, and peace of mind occupied their unconscious thoughts much more than empire and its demise. Like the working class fathers in Sennett and Cobb's study, Nigel wanted his children to have the quality of life he never had, but he also craved the recognition of his estranged daughters, whom he hoped would one day see how much good he could do. Stan too was at least partially invested in becoming a good and lovable father figure, as well as a good and lovable son to his mother, despite his overwhelming identification with the 'badness' of his mother's victimizers and other violent men. As a consequence both men occupied the kinds of embattled mentalities, Stuart Hall, equates with the most vociferous expressions of working class racism, to a large extent explaining their respective identifications with far right extremist groups that had promised to deliver 'rights for whites' humiliated and belittled by hurts that are both irreducibly personal and complexly class based.

\section{Concluding thoughts}

10.1 If we are to take the insights of psychoanalysis seriously in sociological research then we must engage with the meanings of love, hate and loss in individual people's lives. Using biographical material disclosed by two individuals known for their extremely racist attitudes and behaviours, living in a region often depicted as a hotbed for far right extremism, I have endeavoured to put a critical aspect of Paul Gilroy's 'postcolonial melancholia' thesis to the test. My argument has been that while there is evidence to suggest that British racism often takes a form consistent with the pathologies Gilroy attributes to melancholia, it makes little sense, at least at the level of the individual, to assume that today's hatreds are a direct product of a disavowed identification with empire and its crimes. In the cases I have presented it makes more sense to talk about family life and its hurts, the shame of class-based injustices in white communities, or masculinity and the false promises of male power. The various losses inflicted in all of these symbolic domains are, of course, interrelated, in the sense that the problems of child abuse and neglect, poor mental health, domestic violence, and drink and drug abuse coalesce with poverty and the effects of underemployment, even if they are rarely understood in the particular context of deprivation. Each has the potential to thwart healthy psychological development in children and to aggravate the emotional scars left by developmental crises in adults. Humiliation, disrespect and the shame of inadequacy are, sadly, both routine features of some children's lives and among the hidden injuries class and its hurts inflict throughout the life course. Losses of love and feelings of insecurity can be compounded by the violence of adults, who are also losing it mentally; tendencies that are liable to become all the more common in contexts where the certainties of respect, stable employment and community-spiritedness are being destroyed by industrial decline.

10.2 In combination these painful losses 'eat' so many people up inside, rendering them hateful. Meanwhile, racism provides a structure that enables the source of these unsettling feelings to be attributed to those re-imagined to be half-different and partially familiar. In these contexts, loss can, unfortunately, furnish a nostalgic sense of political community obsessed with the protection of exclusively white working class communities unfettered by multiculturalism, immigration and Islam. Persuading men like Nigel and 
Stan to relinquish their investments in racialized fantasies like these is never going to be easy, not least because these fantasies do emotional work for those locked into melancholic reactions to the unbearable losses of their pasts. Finding alternative ways of providing recognition to those who have fought class struggles and lost (as Fromm's classic analysis reminds us), understanding that recognition must address the nature of personal character as much as the social struggles in which it is enmeshed (as Richard Sennett suggests), and finding a means of being responsive to those acutely hateful people whose needs for conditions of liveability and grievability have been repeatedly overlooked across multiple generations (as Judith Butler now argues), are the key challenges that have to be surmounted if we wish to loosen white Briton's lingering dependence on race-thinking post-colonialism.

\section{Acknowledgements}

The author would like to thank Bill Dixon, Tony Jefferson and Robin Robinson for comments, ideas and suggestions which have helped refine the analyses contained in this paper.

\section{Notes}

${ }^{1}$ The research was funded by the Economic and Social Research Council Award number RES-000-23-0171. The data sets generated by the project are lodged with the Economic and Social Data Service http://www.esds.ac.ac.uk. Numbers within square brackets within the excerpts of transcripts documented here represented timed pauses in seconds.

\section{References}

ALEXANDER, C. (2004) 'Imagining the Asian gang: ethnicity, masculinity and youth after 'the riots", Critical Social Policy, 24(4): 526-549. [doi:10.1177/0261018304046675]

BUTLER, J. (2006). Precarious Life: The Powers of Mourning and Violence . London: Verso.

BUTLER, J. (2009). Frames of War: When is Live Grievable? London: Verso.

CHENG, A. (2007) 'Intimate refusals: a politics of objecthood' in M. Suchet, A. Harris, \& L. Aron (Eds.), Relational Psychoanalysis Volume 3 (pp.135-150). London: The Analytic Press.

COWLISHAW, G. (2004) Blackfellas whitefellas and the hidden injuries of race, Oxford: Blackwell.

CRAWLEY, H. (2005) 'Evidence on Attitudes to Asylum and Immigration: What We Know, Don't Know and Need to Know' Centre on Migration, Policy and Society, Working Paper No. 23, University of Oxford <http://www.compas.ox.ac.uk/fileadmin/files/pdfs/Heaven\%20Crawley\%20WP0523.pdf> Last accessed: $15 / 03 / 10$

DAMOUSI, J. (2001) Living with aftermath: Trauma, nostalgia and grief in Post-war Australia , Cambridge: Cambridge University Press. [doi:10.1017/CBO9780511549618]

FREUD, A. (1964) 'Comments on psychic trauma', in A. Freud (1969) The writings of Anna Freud, volume 5 (pp221-241), New York: International Universities Press.

FREUD, S. (1917/1957). 'Mourning and Melancholia'. The Standard Edition of the Complete Psychological Works of Sigmund Freud, Volume XIV (1914-1916): On the History of the Psycho-Analytic Movement, Papers on Metapsychology and Other Works (pp. 237-258). London Hogarth Press/The Institute of Psycho-Analysis.

FROMM, E. (1942/2002). The Fear of Freedom . London: Routledge \& Kegan Paul.

GADD, D., Dixon, B., \& Jefferson T. (2005). Why Do They Do It? Racial Harassment in North Staffordshire. Keele: Centre for Criminological Research, Keele University.

GILROY, P. (2004) After Empire: Melancholia or Convivial Culture? Routledge: London.

GILROY, P. (2006a) Postcolonial Melancholia, New York: Columbia University Press.

GILROY, P. (2006b) 'Multiculture in times of war' Inaugural address to the LSE, Wednesday $10^{\text {th }}$ May, 2006 $<$ http://www2.Ise.ac.uk/publicEvents/pdf/20060510-PaulGilroy.pdf> 
HALL, S. (1999). From Scarman to Stephen Lawrence. History Workshop Journal, 48: 187-97. [doi:10.1093/hwj/1999.48.187]

HARDING, A and Nevin, B. (2009) 'The political economy of disconnected England: Hull, Stoke and dystopia', Paper presented to the ESRC Seminar Series - Regenerating Medium-sized Cities , $29^{\text {th }}$ November, Keele University.

HOLLWAY, W. \& Jefferson, T. (2000) Doing Qualitative Research Differently. London: Sage.

ICM, 2009 'BNP Poll for the News of the World Survey'

http://www.icmresearch.co.uk/pdfs/2009_oct_notw_bnp_poll.pdf Last accessed 21 December 2009.

KLEIN, M. (1935) 'A contribution to the psychogenesis of manic-depressive states'. International Journal of Psycho-Analysis 16: 145-7.

KLEIN, M. (1940) 'Mourning and its relationship with manic-depressive states'. International Journal of Psychoanalysis, 12: 47-82.

LEADER, D. (2009) The new black: mourning, melancholia and depression . London: Penguin.

MCLAREN, L. and Johnson, M. (2007) 'Resources, group conflict and symbols: explaining anti-immigration hostility in Britain', Political Studies, 55(4): 709-732 [doi:10.1111/j.1467-9248.2007.00680.x]

RILEY, J. Cassidy, D. and Becker, J. (2009) Statistics on Race and the Criminal Justice System 2007/8, London: Ministry of Justice, <http://www.justice.gov.uk/stats-race-criminal-justice-system-07-08revised.pdf> Last accessed 15/03/10.

SENNETT, R \& Cobb, J. (1993) The Hidden Injuries of Class. New York: Norton \& Co.

SENNETT, R. (2003). Respect: The Formation of Character in an Age of Inequality. London: Penguin.

STANLEY, L. (2006) Mourning Becomes... Post/Memory, Commemoration and the Concrentration Camps of the South African War, Manchester: Manchester University Press.

WEBSTER, C. (2003) 'Race, space and fear: imagined geographies of racism, crime, violence and disorder in Northern England' Capital \& Class 80: 95-122. [doi:10.1177/030981680308000107]

WELZER, H. (2008) 'Collateral damage of history education: National socialism and the Holocaust in German Family History', Social Research, 75(1): 287-314.

WERBNER, P. (2005) 'The translocation of culture: 'community cohesion' and the force of multiculturalism in history', Sociological Review, 53(4): 745-67. [doi:10.1111/j.1467-954X2005.00594.x]

WINNICOTT, D. (1958) 'Transitional objects' on Collected Papers Volume 1 (pp. 339-42) London: Tavistock. 